Check for updates

Cite this: RSC Adv., 2017, 7, 22433

Received 26th January 2017

DOI: $10.1039 / \mathrm{c} 7 \mathrm{ra01185g}$

rsc.li/rsc-advances
Accepted 9th March 2017

\section{The impact of zeta potential changes on Ceratium hirundinella cell removal and the ability of cells to restore its natural surface charge during drinking water purification}

\begin{abstract}
H. Ewerts, (D) ab S. Barnard ${ }^{\star a}$ and A. Swanepoel ${ }^{b}$
Unit processes of a conventional water purification facility are designed to remove suspended material from source water (both inorganic and organic impurities). Organic substances in source water include phytoplankton species (algae and cyanobacteria) that are generally negatively charged on the surface of the cells. The zeta potential (ZP) of algal cells needs to be destabilized in order to enhance removal thereof during water purification. The aims of this study were to investigate the ZP changes of Ceratium hirundinella ( $C$. hirundinella) cells and the ability of cells to restore their natural ZP during the water purification process. C. hirundinella cells ( $>500$ cells per $\mathrm{mL}$ ) were collected from the Middle Lake in South Africa (coordinates: $26^{\circ} 10^{\prime} 50.40^{\prime \prime} \mathrm{S} ; 2^{\circ} 17^{\prime} 50.11 \mathrm{E}$ ). A six paddle jar test apparatus was used to simulate unit processes under laboratory conditions using 3 different coagulant options. The ZP analyser with a built-in calibrated $\mathrm{pH}$ meter was used to analyse the $\mathrm{ZP}$ and $\mathrm{pH}$ of the cells and the filtered source water. The coagulant concentration of $10 \mathrm{mg} \mathrm{L}^{-1} \mathrm{Ca}(\mathrm{OH})_{2}$ and $10 \mathrm{mg} \mathrm{L}^{-1}$ organic polymer achieved the best coagulation conditions as assessed against an operation ZP window of between $-10 \mathrm{mV}$ to $+3 \mathrm{mV}$. This $\mathrm{Ca}(\mathrm{OH})_{2}$ and organic polymer dosing concentration was used to purify water with increasing cell concentrations (2000 cells per $\mathrm{mL}$ to 7000 cells per $\mathrm{mL}$, increments of 1000) applying settling times of 20 minutes, 120 minutes and 240 minutes. Results obtained indicated high percentages of cell removal after 20 minutes (82-88\%), 120 minutes (93\%) and 240 minutes (95\%) respectively. However, after extended settling times (120-240 minutes), more metabolically active cells were observed in the supernatant of samples containing higher cell concentrations. The findings showed that the ZP of $C$. hirundinella cells changes as a result of adding coagulants to form flocs, but may be restored when water purification facilities employ poor optimization practices and allow extended settling periods or retention times.
\end{abstract}

\section{Introduction}

A wide variety of particulate impurities which include inorganic substances such as clays and metal oxides, various organic colloids and microbes (viruses, bacteria, protozoa and phytoplankton) occur in natural waters. ${ }^{4}$ These suspended particles in solutions such as algal cells in surface water often have a charge on the surface (mostly negatively charged) and the magnitude thereof can be determined electrophoretically. ${ }^{3}$ The conversion of particles in a solution from a stable state to an unstable state (destabilization) can be accomplished in the conventional water treatment processes of coagulation and flocculation $^{3}$ during which these impurities aggregate to form

${ }^{a}$ Unit for Environmental Sciences and Management, North-West University, Private Bag X6001, Potchefstroom, 2520, South Africa. Tel: +27 182992508. E-mail: sandra. barnard@nwu.ac.za

${ }^{b}$ Rand Water Analytical Services, PO Box 3526, Vereeniging, 1930, South Africa flocs. Coagulation and flocculation is the result of the particle collisions and charge interactions between coagulants and surfaces of impurities found in water. ${ }^{9}$ Aggregation of particles in an aqueous solution is influenced by various factors such as surface charge, $\mathrm{ZP}$, aggregation kinetics and the distributions of ions. The $\mathrm{ZP}$ is the electrical potential difference at the hydrodynamic slip plane, the interface between the aqueous fluid and the stationary layer of fluid attached to the bacterial or algal cell. ${ }^{26}$

According to Manciu et al., ${ }^{23}$ the dispersion of ions in aqueous solutions is still a controversial topic, irrespective of the relevance thereof in biological and environmental processes. A study conducted by Alroudhan et al. ${ }^{1}$ found that two cations ( $\mathrm{Ca}$ and $\mathrm{Mg}$ ) changed the $\mathrm{ZP}$ (decreasing the negative magnitude of $\mathrm{ZP}$ ) of intact lime-stone solutions as a result of increasing concentrations. It is evident from previous studies, ${ }^{\mathbf{1 , 1 0 , 2 3}}$ that natural ZP in aqueous solutions are influenced by the addition of ions (anion and cations), which can support aggregation of particles 
suspended in water accomplished by destabilization. When coagulants are added to source water during treatment, positively charged coagulants react with suspended particles (colloidal and dissolved NOM) to aggregate and form flocs that are removed during separation processes such as sedimentation. ${ }^{5}$ The removal of these substances from the source water requires a specific coagulant demand, which affect the required coagulant dose. ${ }^{5}$ For smaller particles, separation efficiency can be greatly enhanced by aggregation; because of their surface charge these aquatic particles are often colloidally stable and resistant to aggregation. ${ }^{4}$

When the magnitude of negative ZP is reduced, the surface charge of the suspended particles such as phytoplankton cells approaches $0 \mathrm{mV}$ (charge neutralization and destabilization), which generally improves coagulation ${ }^{\mathbf{1 4 , 3 3}}$ Therefore the removal of algae during coagulation and flocculation requires that treatment processes are capable of neutralizing algal surface charges to ensure that they are effectively incorporated into flocs. ${ }^{18} \mathrm{ZP}$ can be used to monitor and control coagulation of phytoplankton cells as confirmed by previous studies, ${ }^{\mathbf{9}, \mathbf{1 3}, \mathbf{1 9}, \mathbf{2 7}}$ when using coagulants such as alumimum sulfate, hydrated lime $\left(\mathrm{Ca}(\mathrm{OH})_{2}\right)$, sodium hydroxide, potassium and ammonium hydroxide to induce coagulation conditions. Gerde et al. ${ }^{9}$ also investigated the ZP control of the algae Scenedesmus spp., Chlamydomonas reinhardtii and Schizochytrium limacinum when dosing various cationic coagulants and stated that further research is required to investigate in greater detail how coagulants (or flocculants) change solution $\mathrm{pH}$ and surface $\mathrm{ZP}$ of algal cells to obtain more insights on the flocculation mechanisms involved. Zou et al. ${ }^{34}$ investigated the mechanism of chitosan (a biopolymer) modified soil to remove phytoplankton (algae and cyanobacteria) cells from water and found that the long chain biopolymer with positively charged groups $\left(\mathrm{NH}_{3}{ }^{+}\right)$ captured negatively charged algal cells effectively, while the soils provided the ballast to ensure floc removal during sedimentation.

The cells of dinoflagellate species are described in literature to easily avoid removal during conventional water treatment and penetrate into the final drinking water. ${ }^{7,31}$ Furthermore little is known about the relationship between $\mathrm{ZP}$ of these algal species such as, $C$. hirundinella and optimization of coagulation conditions. In previous studies, cyanobacterial and green algal species were mostly used during ZP investigations to determine the effectiveness of coagulants and coagulant aids. ${ }^{17,33}$ Unlike cyanobacteria cells that are covered with membranes and in some cases mucilage sheaths, the relatively large sized C. hirundinella cells are covered with unique cell coverings (theca plates) with different surface charge characteristics.

A chlorophyll breakthrough event into the treated water due to large numbers of $C$. hirundinella cells entering the final treated water, was observed at South Africa's largest conventional water treatment plant (SALCWTP) during the summer of $2006 .{ }^{31}$ This investigation focuses specifically on the use of $\mathrm{Ca}(\mathrm{OH})_{2}$ and a cationic organic polymer that will be dosed simultaneously and separately as part of the treatment options (as a primary coagulant or coagulant aid) to investigate the influence of ZP on the coagulation conditions of the freshwater dinoflagellate, $C$. hirundinella.

The specific objectives of this study were to (1) investigate the change in ZP of $C$. hirundinella cells during coagulation when using various coagulants to simulate conventional coagulation, flocculation and sedimentation as well as to (2) evaluate whether cells were sufficiently neutralized to remain in aggregation (flocs), or whether cells were able to restore their natural surface charge after sedimentation and swim out of the flocs.

\section{Materials and methods}

\subsection{Source water and sample collection}

Source water samples (approximately $100 \mathrm{~L}$ ) containing high concentrations $C$. hirundinella cells were collected from the Middle Lake in Benoni, Gauteng Province, South Africa (coordinates: $26^{\circ} 10^{\prime} 50.40^{\prime \prime} \mathrm{S} ; 28^{\circ} 17^{\prime} 50.11 \mathrm{E}$ ). Two litre samples were prepared separately for jar tests using the following approach: (1) from the first one litre of sample most algae and bacteria were removed by filtration using $0.45 \mu \mathrm{m}$ filters, (2) from the second one litre sample $C$. hirundinella cells were recovered using a $50 \mu \mathrm{m}$ sieve and then finally (3) the $C$. hirundinella cells recovered with the $50 \mu \mathrm{m}$ sieve were re-suspended in the 0.45 $\mu \mathrm{m}$ filtered water prepared in the first step. This resulted in a source water matrix enriched with $C$. hirundinella cells. Water samples (containing living $C$. hirundinella cells) were stored under laboratory conditions at $\pm 22{ }^{\circ} \mathrm{C}$. Six different C. hirundinella cell concentrations were prepared from a stock sample (containing 7000 cells per $\mathrm{mL}$ ) to obtain a dilution range from 2000 cells per $\mathrm{mL}$ to 7000 cells per $\mathrm{mL}$ (with increments of 1000).

\subsection{Coagulants}

The following coagulants options were dosed within different concentration ranges: (1) hydrated lime in combination with activated silica $\left(\mathrm{Ca}(\mathrm{OH})_{2}-\mathrm{SiO}_{2}\right)$ in the range of $60 \mathrm{mg} \mathrm{L}^{-1}$ to $160 \mathrm{mg} \mathrm{L}^{-1} \mathrm{Ca}(\mathrm{OH})_{2}$ and constant $\mathrm{SiO}_{2}$ concentration (4 mg L ${ }^{-1}$ ); (2) $\mathrm{Ca}(\mathrm{OH})_{2}$ in combination with organic polymer: with the organic polymer in the range of $4 \mathrm{mg} \mathrm{L}^{-1}$ to $14 \mathrm{mg} \mathrm{L}^{-1}$ and a constant $\mathrm{Ca}(\mathrm{OH})_{2}$ concentration $\left(10 \mathrm{mg} \mathrm{L}^{-1}\right)$ and (3) organic polymer in a range of $4 \mathrm{mg} \mathrm{L}^{-1}$ to $14 \mathrm{mg} \mathrm{L}^{-1}$.

\subsection{Jar stirring tests and sampling for analytical determinations}

The conventional water treatment processes coagulation, flocculation and sedimentation were simulated with a jar stirring apparatus (Phipps and Bird, Model 7790-704). Jar stirring experiments were conducted at room temperature $\left( \pm 22{ }^{\circ} \mathrm{C}\right)$; using six 2 litre beakers filled with $C$. hirundinella enriched filtered source water. Known concentrations of different coagulants were added with syringes. The 2 litre $(2 \mathrm{~L})$ jar beakers with filtered source water containing pre-determined C. hirundinella cell concentrations were subjected to high energy jar stirring test conditions. Different coagulant concentrations were added with syringes and allowed to disperse uniformly at high energy flash mixing conditions. High energy flash mixing 
conditions of $300 \mathrm{rpm}$ ( $G$-value of $400 \mathrm{~s}^{-1}$ ) for 30 seconds, followed by the following decreasing $G$-values: $125 \mathrm{~s}^{-1}, 54 \mathrm{~s}^{-1}$ and $14 \mathrm{~s}^{-1}$ were applied. Stirring paddles were switched off to allow flocs to settle for 20 minutes. After conducting jar stirring tests the following samples were collected to perform specific analyses:

- Samples were collected from the supernatant after treatment with different coagulants to perform $\mathrm{pH}$ and C. hirundinella cell count analyses.

- Supernatant samples containing flocs were collected to perform ZP analyses after water treatment with various coagulants after 20 minutes and again after 120 minutes and 240 minutes.

\section{$2.4 \mathrm{ZP}$ and $\mathrm{pH}$}

The ZetaPlus ZP analyser, manufactured by Brookhaven Instruments Corporation (model: BI-ZR3) (range of $\pm 150 \mathrm{mV}$ ) was used to perform ZP measurements (laser specifications: 35 $\mathrm{mW}$ solid state laser, red, $660 \mathrm{~nm}$ wavelength; optional: $50 \mathrm{~mW}$ green, $532 \mathrm{~nm}$ ). Approximately $1.6 \mathrm{~mL}$ of sample was transferred into square cuvettes and the electrodes of the ZetaPlus analyser were submerged into the sample. The surface charge of C. hirundinella cells was measured using the ZP Analyser software. Each $\mathrm{ZP}$ value is the average of 10 readings. The $\mathrm{pH}$ meter built into the ZetaPlus Analyser (calibrated $\mathrm{pH}$ probe) was used to determine the $\mathrm{pH}$ of samples simultaneously with ZP.

\subsection{Ceratium hirundinella cell identification and enumeration}

Source water and treated water $(1000 \mathrm{~mL})$ samples were collected and filtered through $0.45 \mu \mathrm{m}$ filter paper to trap $C$. hirundinella cells. Cells trapped on filter paper were recovered and re-suspended in $10 \mathrm{~mL}$ using a vortex mixer. Samples were preserved with Lugol's solution ( $1 \mathrm{~mL}$ per $100 \mathrm{~mL}$ of sample) or $32 \%$ formaldehyde ( $2 \mathrm{~mL}$ per $100 \mathrm{~mL}$ of sample). The sedimentation/centrifugation technique, originally described by Lund et $a .^{21}$ and adapted for Rand Water according to Swanepoel et al. ${ }^{31}$ was used for identification and enumeration. The concentration (cells per $\mathrm{mL}$ ) and physical integrity of $C$. hirundinella cells were determined and evaluated using an inverted light microscope. All experiments were conducted in triplicate and the results were presented as the mean values.

\subsection{Statistical analyses}

Normality tests were performed in XLSTAT version 2014.1.07 for $\mathrm{pH}$ and $\mathrm{ZP}$ data. The following normality tests indicated a normal distribution for all data: Shapiro-Wilks, AndersonDarling, Lillieforst and Jarque-Bera. A single factor analysis of variance (ANOVA) was performed to determine if there was a statistically significant difference between the average values of $\mathrm{ZP}$ and $\mathrm{pH}$ measurement determined in the source water (control) and after different coagulant treatments or after different settling times. ANOVA was performed using GraphPad Prism for Windows version 4.00. The level of significance for all statistical analyses was set at 0.05 ( $p$-value) and the hypotheses were stated separately for each analysis with the hypothesised difference equal to zero.

\section{Results}

\subsection{ZP, pH measurements and $C$. hirundinella cell concentration before (in source water) and after (after sedimentation) different coagulant treatments}

Table 1 displays the $\mathrm{ZP}$ and $\mathrm{pH}$ values of $C$. hirundinella cells in filtered source water collected from Middle Lake in Benoni. The concentrations of $C$. hirundinella cells re-suspended in filtered source water varied between 392 and 616 cells per $\mathrm{mL}$ with an average $\mathrm{ZP}$ and $\mathrm{pH}$ values of $-13.38 \mathrm{mV}$ and $8.79 \mathrm{mV}$ respectively during five different sampling occasions.

Table 1 The ZP of $C$. hirundinella cells, $\mathrm{pH}$ and cell concentrations recorded during five sampling occassions (Sampling 11 January-8 February 2012) collected from the Middle Lake source water $(n=5$; \pm standard deviation)

\begin{tabular}{lrll}
\hline Sampling occassions & $\mathrm{ZP}(\mathrm{mV})$ & $\mathrm{pH}$ & $\begin{array}{l}\text { C. hirundinella } \\
\text { (cells per mL) }\end{array}$ \\
\hline 1 & -12.43 & 8.63 & 392 \\
2 & -9.67 & 8.95 & 594 \\
3 & -14.90 & 8.82 & 538 \\
4 & -14.83 & 8.75 & 515 \\
5 & -15.05 & 8.81 & 616 \\
Average values & $-\mathbf{1 3 . 3 8}$ & $\mathbf{8 . 7 9}$ & $\mathbf{5 3 1}$ \\
Standard deviation & $\mathbf{2 . 3 4}$ & $\mathbf{0 . 1 2}$ & $\mathbf{8 7 . 7 8}$ \\
& & &
\end{tabular}

(a)

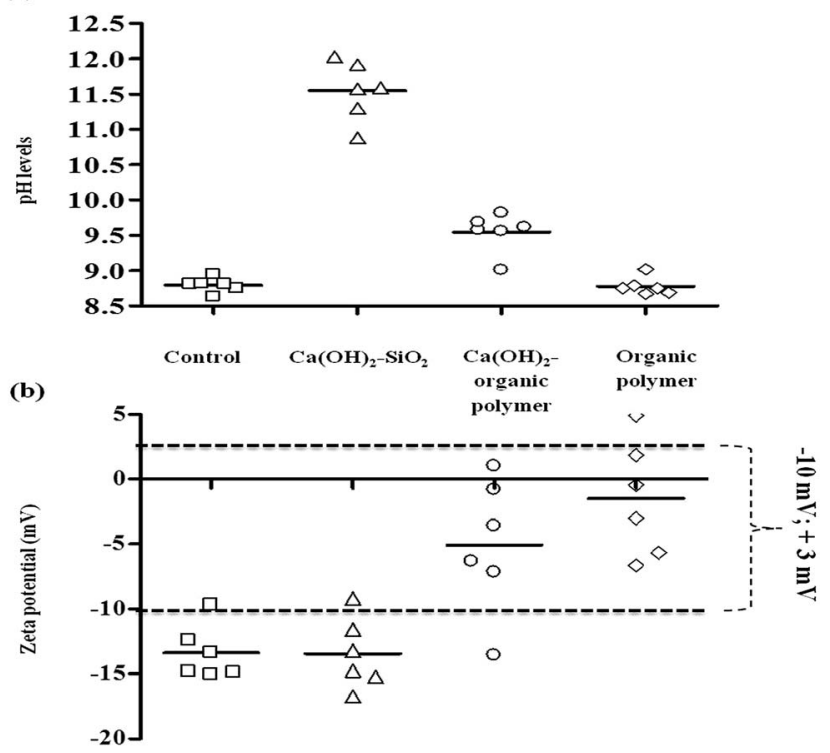

Fig. 1 Screening test results of $\mathrm{pH}$ and $\mathrm{ZP}$ for the selection of an appropriate coagulant chemical option range. Dotted lines indicate the $\mathrm{ZP}$ range required for good coagulation. $\mathrm{Ca}(\mathrm{OH})_{2}$ concentrations ranged from $60 \mathrm{mg} \mathrm{L}^{-1}$ to $160 \mathrm{mg} \mathrm{L}^{-1}$ (equal increment of 20), $\mathrm{SiO}_{2}$ concentrations were constant as $4 \mathrm{mg} \mathrm{L}^{-1}$ (coagulant aid). Concentrations of $\mathrm{Ca}(\mathrm{OH})_{2}$ in combination with organic polymer were $10 \mathrm{mg}$ $\mathrm{L}^{-1}$ as a coagulant aid, while organic polymer concentrations were dosed in a range of $4 \mathrm{mg} \mathrm{L}^{-1}$ to $14 \mathrm{mg} \mathrm{L}^{-1}$. 
Fig. 1 displays the changes in $\mathrm{pH}$ values and $\mathrm{ZP}$ values after dosing different coagulant ranges for $\mathrm{Ca}(\mathrm{OH})_{2}-\mathrm{SiO}_{2}, \mathrm{Ca}(\mathrm{OH})_{2}-$ organic polymer and organic polymer. The $\mathrm{ZP}$ range proposed by Sharp et al. ${ }^{28}$ required for good coagulation $(-10 \mathrm{mV}$ to +3 $\mathrm{mV}$ ) is indicated by the dotted line in Fig. $1 \mathrm{~b}$ and will be used to evaluate the efficacy of coagulants to meet optimum coagulation conditions. The efficacy of coagulants to meet the required surface charge changes will be evaluated using the initial negative ZP values recorded in the table above for C. hirundinella cells against the values obtained after treatment with different coagulant options.

The magnitude of negative $\mathrm{ZP}$ values measured for the $\mathrm{Ca}(\mathrm{OH})_{2}-\mathrm{SiO}_{2}$ treatment option were not reduced effectively to achieve appropriate coagulation $\mathrm{ZP}$ values within the range of $-10 \mathrm{mV}$ to $+3 \mathrm{mV}$. In contrast to $\mathrm{Ca}(\mathrm{OH})_{2}-\mathrm{SiO}_{2}, \mathrm{Ca}(\mathrm{OH})_{2}-$ organic polymer and organic polymer were able to reduce the magnitude of negative ZP on C. hirundinella cells in the filtered raw water suspension (Fig. 1b). The $\mathrm{pH}$ measurements showed a significant increase at the lowest $\mathrm{Ca}(\mathrm{OH})_{2}$ concentration in combination with $\mathrm{SiO}_{2}$ from $\mathrm{pH} 8.79$ (control) to $\mathrm{pH}$ levels above 10.50 , where-after an increasing $\mathrm{pH}$ trend was recorded as a result of increased coagulant concentrations (Fig. 1a). When dosing $\mathrm{Ca}(\mathrm{OH})_{2}$ in combination with $\mathrm{SiO}_{2}$, the lowest $\mathrm{Ca}(\mathrm{OH})_{2}$ concentration of $60 \mathrm{mg} \mathrm{L}^{-1}$ caused the initial $\mathrm{ZP}$ to decrease (Fig. 1b; from $-13.38 \mathrm{mV}$ to $-16.71 \mathrm{mV}$ ). However, the subsequent increasing $\mathrm{Ca}(\mathrm{OH})_{2}$ concentrations showed an increasing $\mathrm{ZP}$ trend, but it remained below the proposed $\mathrm{ZP}$ range required for good coagulation conditions.

Increased $\mathrm{pH}$ levels ( $>\mathrm{pH}$ 9.70) were recorded for the lowest organic polymer concentration which can be an ascribed to the low constant $\mathrm{Ca}(\mathrm{OH})_{2}$ dosage of $10 \mathrm{mg} \mathrm{L}^{-1}$. The organic polymer concentration of $4 \mathrm{mg} \mathrm{L}^{-1}$ in combination with $\mathrm{Ca}(\mathrm{OH})_{2}(10 \mathrm{mg}$ $\mathrm{L}^{-1}$ ) kept the initial $\mathrm{ZP}$ of $-13.38 \mathrm{mV}$ relatively constant at a value of $-13.57 \mathrm{mV}$, but an increase in $\mathrm{ZP}$ values were recorded when organic polymer concentrations were increased. ZP values for organic polymer flocculant $\left(4-14 \mathrm{mg} \mathrm{L}^{-1}\right)$ in combination with $\mathrm{Ca}(\mathrm{OH})_{2}\left(10 \mathrm{mg} \mathrm{L} \mathrm{L}^{-1}\right)$ were mostly within the proposed $\mathrm{ZP}$ range required for good coagulation conditions (Fig. 1b). The concentration of $10 \mathrm{mg} \mathrm{L}^{-1}$ for organic polymer was identified as the most optimal within the range of $4 \mathrm{mg} \mathrm{L}^{-1}$ to $14 \mathrm{mg} \mathrm{L}^{-1}$, while for $\mathrm{Ca}(\mathrm{OH})_{2}$ was kept constant at $10 \mathrm{mg} \mathrm{L}^{-1}$ as the coagulant aid for $\mathrm{pH}$ adjustments.

Organic polymer (4-14 $\mathrm{mg} \mathrm{\textrm {L } ^ { - 1 }}$ ) treatment without low $\mathrm{Ca}(\mathrm{OH})_{2}$ concentration $\left(10 \mathrm{mg} \mathrm{L}^{-1}\right)$ caused no $\mathrm{pH}$ adjustments, since $\mathrm{pH}$ levels remained similar to the control (Fig. 1a). The ZP value range was closer to $0 \mathrm{mV}(-6.64 \mathrm{mV}$ to $+4.90 \mathrm{mV})$ than what was observed for $\mathrm{Ca}(\mathrm{OH})_{2}$-organic polymer range that was recorded between $-13.57 \mathrm{mV}$ and $+1.00 \mathrm{mV}$ as illustrated Fig. 1b. ANOVA results also indicate that after treating source water containing $C$. hirundinella cells with various coagulant ranges, the average $\mathrm{pH}$ values $(p=<0.0001)$ and $\mathrm{ZP}$ values $(p=$ $<0.0001)$ were significantly different compared to the control (Fig. 1a and b).

When dosing $\mathrm{Ca}(\mathrm{OH})_{2}$ in combination with $\mathrm{SiO}_{2}$ and $\mathrm{Ca}(\mathrm{OH})_{2}$ in combination with organic polymer, the $\mathrm{pH}$ increased from 8.79 to 11.5 and 9.5 respectively, while organic polymer alone was not able to change the $\mathrm{pH}$ of the filtered source water (Fig. 1a). Although the $\mathrm{pH}$ levels were significantly increased by $\mathrm{Ca}(\mathrm{OH})_{2}-\mathrm{SiO}_{2}$ treatment, the $\mathrm{ZP}$ values remained constant when compared to the $\mathrm{ZP}$ values (mostly $\leq-10 \mathrm{mV}$ ) recorded in the source water (Fig. 1b). On the other hand, both $\mathrm{Ca}(\mathrm{OH})_{2}$-organic polymer and organic polymer exhibited changes in the $\mathrm{ZP}$ values from $\leq-10 \mathrm{mV}$ to $\geq-5 \mathrm{mV}$ (Fig. 1b). It was clear from the results that $\mathrm{Ca}(\mathrm{OH})_{2}-\mathrm{SiO}_{2}$ did not influence the $\mathrm{ZP}$ and organic polymer alone was not able to influence the $\mathrm{pH}$, but $\mathrm{Ca}(\mathrm{OH})_{2}$-organic polymer was able to influence both $\mathrm{ZP}$ and $\mathrm{pH}$ to achieve more effective coagulation conditions.

\subsection{Using a constant established coagulant dose to treat source water enriched with different $C$. hirundinella cell concentrations and with different settling times}

Table 2 gives the initial $\mathrm{ZP}$ of $C$. hirundinella cells and $\mathrm{pH}$ values of filtered source water containing different $C$. hirundinella cell concentrations. The initial $\mathrm{ZP}$ values varied between $-13 \mathrm{mV}$ and $-21 \mathrm{mV}$, while the $\mathrm{pH}$ values varied between $\mathrm{pH} 6.97$ and $\mathrm{pH} 7.34$.

The magnitude of ZP (average $-13.38 \mathrm{mV}$ ) measured for $C$. hirundinella cells in natural source water (Table 1) was reduced to $-21 \mathrm{mV}$ for some of the concentrated $C$. hirundinella suspensions (Table 2). A decrease in $\mathrm{pH}$ values were observed from an average $\mathrm{pH}$ of 8.79 in the source water (Table 1) to $\mathrm{pH}$ values varying between $\mathrm{pH} 6.97$ and $\mathrm{pH} 7.34$ recorded for the six concentrated $C$. hirundinella suspensions (Table 2).

For the different cell concentrations (2000-7000 cells per $\mathrm{mL}$ ) the organic polymer dose per cell varied from $5.5 \mathrm{ng}$ per cell to $1.5 \mathrm{ng}$ per cell. Therefore, less coagulant becomes available as a result of increasing cell concentrations. The percentage removal achieved after a settling time of 20 minutes (which is the appropriate settling time simulation of a treatment plant by means of a jar stirring test) varied from $82 \%$ to $88 \%$. After 120 minutes and 240 minutes the percentage removal was improved to percentages up to $93 \%$ and $95 \%$ respectively (Fig. 2). An increasing trend for the number of cells not removed, was recorded after treatment of the supernatant possibly as a result of the increasing initial cell concentration and constant optimized coagulant concentrations. Extended settling times up to 120 minutes or 240 minutes improved the percentage removal to relatively similar percentage removals $>90 \%$.

Table 2 The ZP and pH measurements of the six pre-determined initial $\mathrm{C}$. hirundinella concentrations that were used in simulated jar stirring test experiments with $\mathrm{Ca}(\mathrm{OH})_{2}$-organic polymer (average values of 30 readings)

\begin{tabular}{|c|c|c|c|c|c|c|}
\hline C. hirundinella concentrations (cells per $\mathrm{mL}$ ) & 2000 & 3000 & 4000 & 5000 & 6000 & 7000 \\
\hline $\mathrm{ZP}(\mathrm{mV})$ & -21 & -21 & -17 & -13 & -17 & -19 \\
\hline $\mathrm{pH}$ & 6.97 & 7.14 & 7.18 & 7.26 & 7.31 & 7.34 \\
\hline
\end{tabular}




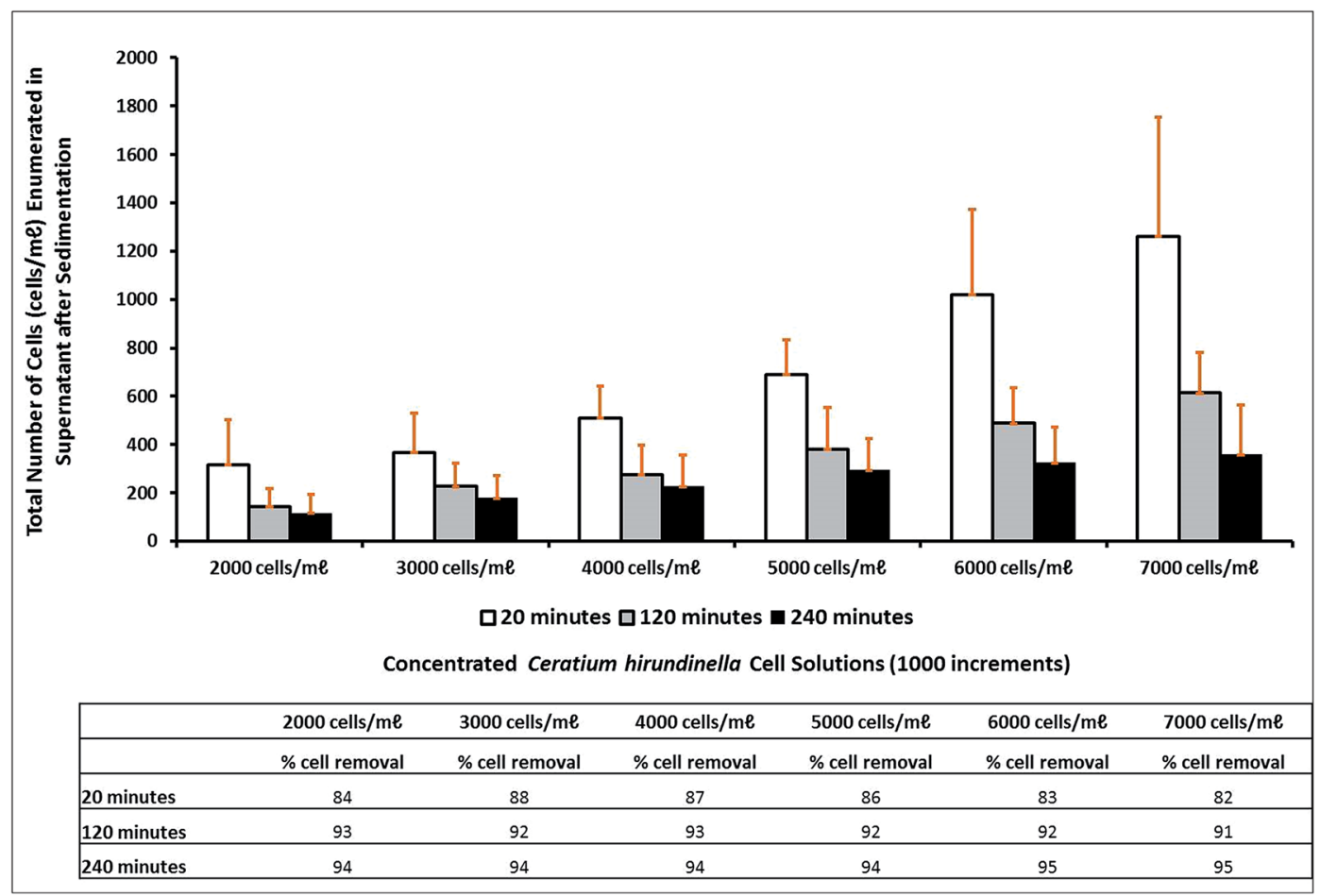

Fig. 2 The percentage of C. hirundinella cells removed after settling times of 20 minutes $(\square), 120$ minutes $(\square)$ and 240 minutes $(\square)$ after dosing a combination of $\mathrm{Ca}(\mathrm{OH})_{2}=10 \mathrm{mg} \mathrm{L}^{-1}$ and organic polymer $=11 \mathrm{mg} \mathrm{L}^{-1}$.

The following ZP values were recorded in source water containing different initial $C$. hirundinella cell concentrations from 2000 cells per $\mathrm{mL}$ to 7000 cells per $\mathrm{mL}$ (increments of 1000): $-21 \mathrm{mV},-21 \mathrm{mV},-17 \mathrm{mV},-13 \mathrm{mV},-17 \mathrm{mV}$ and $-19 \mathrm{mV}$ respectively (Table 2). After a settling time of 20 minutes, the initial ZP values were reduced to the proposed range of $-10 \mathrm{mV}$ to $+3 \mathrm{mV}$ for good coagulation conditions. The best average $\mathrm{ZP}$ value $(-3.28 \mathrm{mV})$ was recorded after treating source water with the highest initial $C$. hirundinella cell concentrations
(Fig. 3). After extended settling periods (up to 120 minutes and 240 minutes), the ZP values have shown a slight change towards restoration of surface charge, notably for suspensions containing higher initial C. hirundinella cell concentrations (6000-7000 cells per mL) (Fig. 3).

The $\mathrm{pH}$ changing factor for source water with increasing initial cell concentration was constant at a concentration of $10 \mathrm{mg} \mathrm{L}^{-1}$ for $\mathrm{Ca}(\mathrm{OH})_{2}$. The $\mathrm{pH}$ levels recorded after a settling time of 20 minutes varied between $\mathrm{pH} 9.64$ and $\mathrm{pH} 9.75$, which

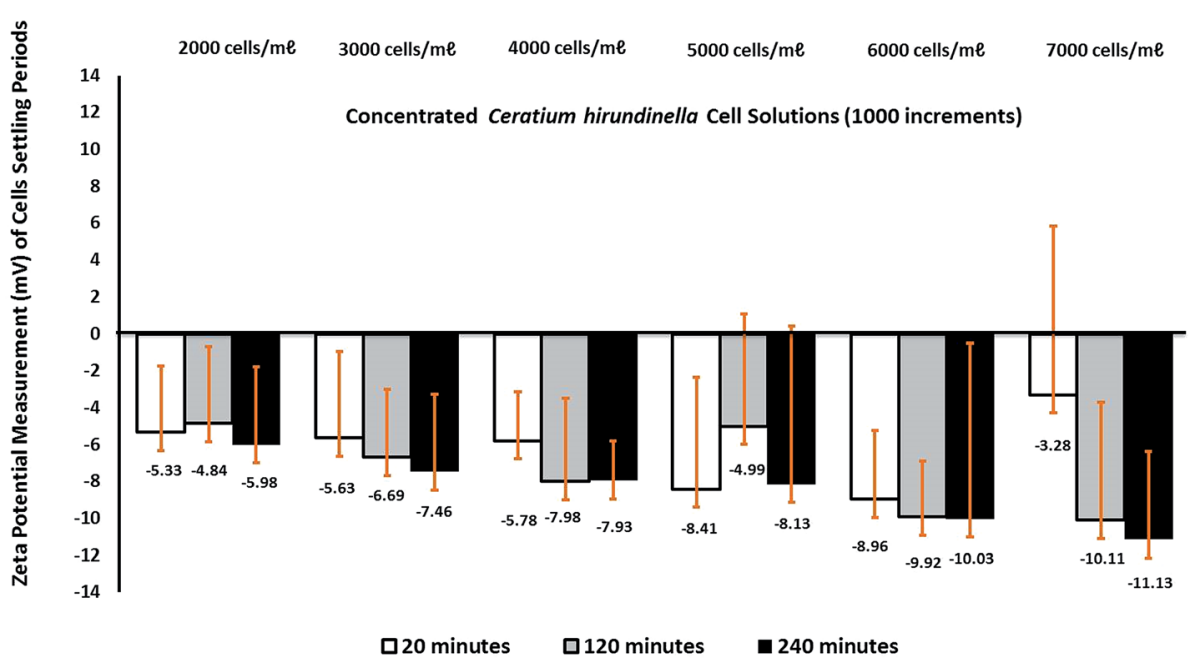

Fig. 3 The changes in ZP after different settling times (20 minutes $(\square), 120$ minutes $(\square)$ and 240 minutes $(\square)$ ) when dosing the same coagulant concentrations $\left(\mathrm{Ca}(\mathrm{OH})_{2}=10 \mathrm{mg} \mathrm{L}^{-1}\right.$; organic polymer $\left.=11 \mathrm{mg} \mathrm{L}^{-1}\right)$ to treat water with increasing $C$. hirundinella cell concentrations. 


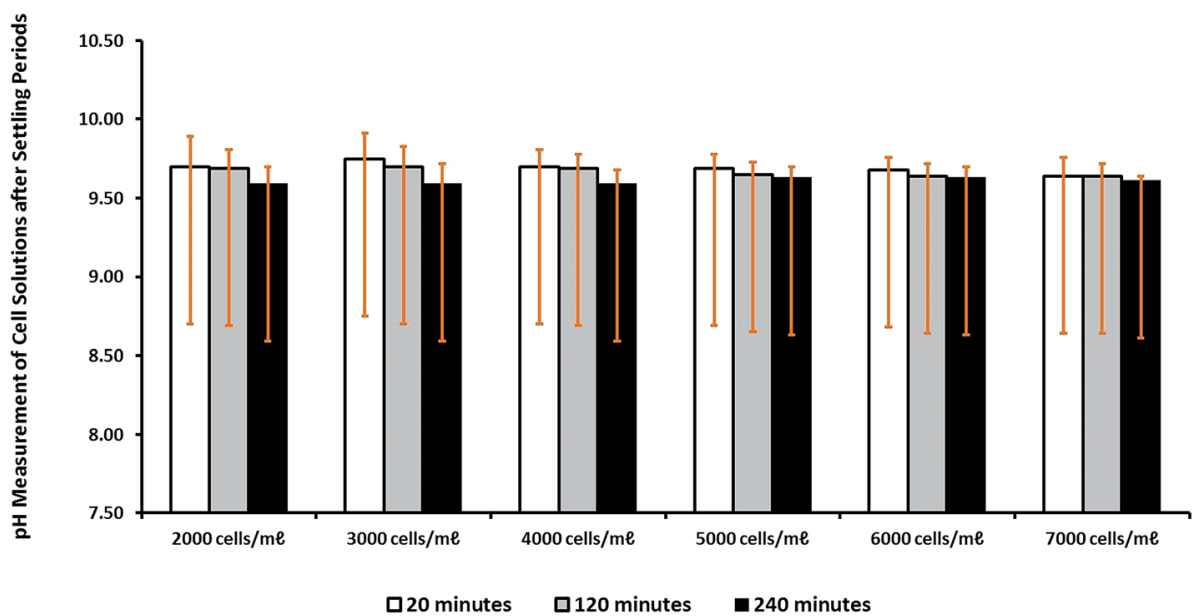

Concentrated Ceratium hirundinella Cell Solutions (1000 increments)

Fig. 4 The pH levels measured in the supernatant after different settling times (20 minutes $(\square), 120$ minutes $(\square)$ and 240 minutes $(\square)$ ) when dosing the same coagulant concentrations $\left(\mathrm{Ca}(\mathrm{OH})_{2}=10 \mathrm{mg} \mathrm{L}^{-1}\right.$; organic polymer $\left.=11 \mathrm{mg} \mathrm{L}^{-1}\right)$ to treat water with increasing $C$. hirundinella cell concentrations.

were the highest $\mathrm{pH}$ levels. The $\mathrm{pH}$ changes measured after different settling times were relatively similar around pH 9.5-9.6 as expected for the a $\mathrm{Ca}(\mathrm{OH})_{2}$ concentration of $10 \mathrm{mg} \mathrm{L}^{-1}$ (Fig. 4).

\section{Discussion}

Within conventional drinking water treatment plants the processes of coagulation and flocculation are considered to be principally responsible for removing negatively charged algae. ${ }^{\mathbf{1 2}}$ These processes are followed by sedimentation as particles cluster together and their settling rates increase. ${ }^{32}$ Ineffective coagulation conditions for algal removal can however be monitored and corrected by controlling the magnitude of $\mathrm{ZP}$ of the algal cells to subsequently avoid water treatment difficulties.

The source water (collected from Middle Lake) used during this investigation contained relatively high $C$. hirundinella cell concentrations ( $>500$ cells per $\mathrm{mL}$ ); therefore, coagulant optimization strategies should form part of the water treatment process. The laboratory-scale simulations of coagulation, flocculation and gravity sedimentation (conducted with a six paddle jar stirrer apparatus) used, were based on South Africa's largest conventional water treatment plant's (SALCWTP) treatment conditions, where the use of $\mathrm{Ca}(\mathrm{OH})_{2}$ is a unique practice as primary coagulant or a coagulant aid. ${ }^{7,8}$ High $\mathrm{Ca}(\mathrm{OH})_{2}$ concentrations (ranging between 60 and $160 \mathrm{mg} \mathrm{L}^{-1}$ ) have proved to increase the $\mathrm{pH}$ of the source water significantly $(>\mathrm{pH} 11.5$ after sedimentation), while a lower constant concentration of $\mathrm{Ca}(\mathrm{OH})_{2}\left(10 \mathrm{mg} \mathrm{L^{-1 }}\right)$ in combination with organic polymer increased the $\mathrm{pH}$ only moderately $(>\mathrm{pH}$ 9.5).

Algal cells such as $C$. hirundinella are expected to flocculate or form flocs in a $\mathrm{ZP}$ operating window of $-10 \mathrm{mV}$ to $+3 \mathrm{mV} .^{28}$ However according to Shen et al. ${ }^{29}$ algae are generally expected to be negatively charged with a $\mathrm{ZP}$ larger than $-40 \mathrm{mV}$, which is difficult to be decreased in order to form a stable floc. This range as opposed to a single $\mathrm{ZP}$ value $(0 \mathrm{mV})$ suggests that in general, colloidal destabilization occurs before complete charge neutralization of surface charge takes place. ${ }^{6,16,25}$ C. hirundinella cells with an average ZP measurement of $-13.38 \mathrm{mV}$ in natural source water was attained for this study, which should therefore have less difficulty to form stable flocs provided that the sufficient coagulant concentration is added. During this investigation no significant changes in $\mathrm{ZP}$ of the $C$. hirundinella cells occurred as a result of high $\mathrm{Ca}(\mathrm{OH})_{2}$ concentration in combination with activated silicate $\left(\mathrm{SiO}_{2}\right)$. On the other hand, it was observed that the magnitude of negative $\mathrm{ZP}$ was reduced as a result of dosing $\mathrm{Ca}(\mathrm{OH})_{2}$ in combination with organic polymer or when dosing organic polymer separately. A low $\mathrm{Ca}(\mathrm{OH})_{2}$ concentration $\left(10 \mathrm{mg} \mathrm{L}^{-1}\right)$ as coagulant aid in combination with $10 \mathrm{mg} \mathrm{L}{ }^{-1}$ organic polymer showed the best results and this combination have impacted on both the $\mathrm{pH}(>9.5)$ and $\mathrm{ZP}$ $(-6.64 \mathrm{mV}$ to $+4.90 \mathrm{mV})$. The adjustment of $\mathrm{pH}$ by adding, among others, $\mathrm{Ca}(\mathrm{OH})_{2}, \mathrm{NaOH}$ and $\mathrm{Na}_{2} \mathrm{CO}_{3}$ promotes alkalinity which will affect not only the buffer capacity of the solution but also decrease the $\mathrm{ZP}$ values. ${ }^{20}$ This finding provides evidence that use of positively charged organic polymer treatments are effective to destabilise and increase the negative ZP charges of cells in suspension sufficiently to promote coagulation. A similar investigation conducted by Jameson ${ }^{\mathbf{1 5}}$ showed that as the organic polymer concentration increased, an increase in the $\mathrm{ZP}$ is observed until it eventually crosses the isoelectric point and becomes positively charged. This finding is confirmed in Fig. 1, where most of the ZP values are recorded within the ZP operating window $(-10 \mathrm{mV}$ to $+3 \mathrm{mV})$ close to the isoelectric point.

Henderson et al. ${ }^{11}$ observed that algae may not start to form flocs until 7 minutes of slow mixing has passed, which was adequately provided for during this study as a lag time for charge neutralization. After a settling time of 20 minutes good removal of cells were observed (Fig. 2), which can be ascribed to 
effective charge destabilisation reducing initial $\mathrm{ZP}$ values to the coagulation operating window $(-10 \mathrm{mV}$ to $+3 \mathrm{mV})$ under good coagulation conditions (e.g. $>\mathrm{pH}$ 9). Improvements in removal efficiencies were observed (from a maximum of $88 \%$ to a maximum of $95 \%$ ) as a result of extended settling periods (up to 120 minutes and 240 minutes). The retention times for floc settling in large gravity sedimentation tanks as observed at SALCWTP last maximally 240 minutes.

Bernhardt et al. ${ }^{2}$ stated that when algae concentrations in source water fluctuate, the concentrations of negative charges in the source water and the coagulant dose required for the neutralization these charges can vary rapidly. During this study increasing negative magnitudes for $\mathrm{ZP}$ (up to $-21 \mathrm{mV}$ ) were observed in most of the suspensions containing higher cell concentrations $(\geq 2000$ cells per $\mathrm{mL}$ ) while $\mathrm{pH}$ values were slightly lower (ranging between pH 6.97 and pH 7.34). Surface charge restoration tendencies were observed after extended settling periods, even in suspensions with low initial cell concentrations (2000-3000 cells per $\mathrm{mL}$ ). The restoration of ZP observed in higher initial cell concentrations (6000-7000 cells per $\mathrm{mL}$ ) can possibly be due to the fact that with increasing cell concentrations less of the coagulant is available per cell. However, a study on the ZP of two cyanobacteria cells belonging to the genera Planktothrix sp. and Synechococcus sp. indicated that cells may also metabolically control cell surface charge to electrostatically attract bicarbonate anions at alkaline $\mathrm{pH}$, required for photosynthesis. ${ }^{22}$ Algal cells can also regulate their surface charge by ion transport across the cell wall. ${ }^{18}$ Pieterse and Cloot $^{24}$ also stated that if algal cells are in equilibrium with themselves, it is possible that the negative surface charge of algal cells will be restored after charge neutralization. This apparent surface charge recovery can be ascribed to metabolic processes such as photosynthesis and respiration ${ }^{24}$ rather than changes in $\mathrm{pH}$. This statement is also supported by Martinez et $a .^{22}$ who found that the ZP for dead, but non-acidified Synechococcus sp. remained negative (at $-30 \mathrm{mV}$ from an initial $\mathrm{pH}$ of 5.6 to 10.5), reflecting that metabolically active cells definitely have the ability to restore its natural surface charge.

\section{Conclusions}

Natural source water samples were used to evaluate efficacy of different coagulant options to achieve the best coagulation conditions, with emphasis on the $\mathrm{ZP}$ operating window $(-10 \mathrm{mV}$ to $+3 \mathrm{mV})$ and to record the alkaline $\mathrm{pH}$ values associated with the effective $\mathrm{ZP}$ range required for floc formation. The ZP of the freshwater dinoflagellate $C$. hirundinella cells in natural source water varied between $-9.67 \mathrm{mV}$ and $-15.05 \mathrm{mV}$ at $\mathrm{pH}$ levels around 8.79, while $\mathrm{ZP}$ in prepared cell solutions with higher cell concentrations varied between $-13 \mathrm{mV}$ and $-21 \mathrm{mV}$ around neutral $\mathrm{pH}$ levels ( $\mathrm{pH}$ 6.97-7.34).

The coagulant option consisting of a constant $\mathrm{Ca}(\mathrm{OH})_{2}$ concentration of $10 \mathrm{mg} \mathrm{L}^{-1}$ (added as a coagulant aid) in combination with an organic polymer range $\left(4 \mathrm{mg} \mathrm{L}^{-1}\right.$ to $14 \mathrm{mg}$ $\mathrm{L}^{-1}$ ) achieved the best coagulation conditions. The optimal concentrations for both the coagulant aid and organic polymer were $10 \mathrm{mg} \mathrm{L}^{-1}$. This concentration was selected for $\mathrm{Ca}(\mathrm{OH})_{2}$ and organic polymer to evaluate the ability of $C$. hirundinella cells to restore its ZP after 20 minutes, 120 minutes and 240 minutes using increasing cell concentrations (2000 cells per $L$ to 7000 cells per $L$ with equal increments of 1000). It was observed that when these concentrations of coagulants are added to filtered source water solutions with increasing cell concentrations, more cells that are metabolically active will be present. This results in C. hirundinella cells floating or swimming in the supernatant or cells not forming part of flocs/aggregates that will be carried over to the next stage of water purification. In the event when high $C$. hirundinella cell concentrations enters a water purification facilities, effective monitoring and optimization strategies should be implemented to ensure coagulant concentrations are added that will achieve $\mathrm{ZP}$ for and $\mathrm{pH}$ conditions to form stable flocs with less cells floating in the supernatant. ZP changes of $C$. hirundinella cells occur as a result adding coagulants to form flocs, but may be restored when water purification facilities employ poor optimization practices and allow extended settling periods or retention times.

\section{Acknowledgements}

The authors express their sincere gratitude to Analytical Services, Scientific Services of Rand Water in South Africa for their financial support and providing their facilities to conduct the research. In addition, Prof. H. H. Du Preez (Rand Water, South Africa) and Dr S. Janse van Vuuren (North-West University, South Africa) for their support and scientific inputs.

\section{References}

1 A. Alroudhan, J. Vinogradov and M. D. Jackson, Colloids Surf., A, 2016, 493, 83-98.

2 H. Bernhardt, B. Lüsse and O. Hoyer, Journal of WaterWastewater Research, 1986, 19, 219-228.

3 BIC (Brookhaven Instruments Corporation), Holtsville, New York 11742, 2002.

$4 \mathrm{~J}$. Duan and J. Gregory, Advances in Colloidal and Interface Science, 2003, 100-102, 475-502.

5 J. K. Edzwald, D. J. Pernitsky and W. L. Parmenter, Article in Chemical Water and Wastewater Treatment VI, Polyaluminum Coagulants for Drinking Water Treatment: Chemistry and Selection, ed. H. H. Hahn, E. Hoffmann and H. Ødegard, Springer, Berlin, Heidelberg, New York, 2000.

6 B. Eikkebrokk, T. Juhna and S. W. Østerus, TECHNEAU D, 2006, 5.3.1a, 1-107.

7 H. Ewerts, S. Barnard, A. Swanepoel, H. H. Du Preez and S. Janse van Vuuren, Water Sci. Technol.: Water Supply, 2014, 14(5), 820-828.

8 H. Ewerts, A. Swanepoel, H. H. Du Preez and N. van Der Walt, J. Water Supply: Res. Technol.-AQUA, 2015, 64(1), 1-8.

9 J. A. Gerde, L. Yao, J. Y. Lio, Z. Wen and T. Wang, Algal Res., 2014, 3, 30-35.

10 H. He, Y. Cheng, C. Yang, G. Zeng, C. Zhu and Z. Yan, J. Environ. Sci., 2016, DOI: 10.1016/j.jes.2016.06.009.

11 R. K. Henderson, E. Sharp, P. Jarvis, S. Parsons and B. Jefferson, Water Sci. Technol.: Water Supply, 2006, 6, 31-38. 
12 R. K. Henderson, S. A. Parsons and B. Jefferson, Water Res., 2008a, 42(8-9), 1827-1845.

13 R. K. Henderson, S. A. Parsons and B. Jefferson, Sep. Sci. Technol., 2008b, 43(7), 1653-1666.

14 M. Hjorth and B. U. Jorgensen, Water Res., 2012, 46(4), 10451051.

15 G. J. Jameson, Colloids Surf., A, 1999, 151, 269-281.

16 B. Jefferson, E. L. Sharp, E. Goslan, R. K. Henderson and S. A. Parsons, Water Sci. Technol.: Water Supply, 2004, 4(56), 49-56.

17 H. Jun, Y. Lee, B. Lee and D. R. U. Knappe, J. Water Supply: Res. Technol.-AQUA, 2001, 50(3), 135-148.

18 D. R. U. Knappe, R. C. Belk, D. S. Briley, S. R. Grandy, N. Rastogi and A. H. Rike, AWWA Research Foundation, 2004, 1-466.

19 L. Li, H. Zhang and G. Pan, J. Environ. Sci., 2015, 28, 47-53. 20 H. Lohtaja, Bio-ja elintarviketekniikka, Laboratory Technology, Turku University of Applied Sciences, City of Turka, Finland, 2005.

21 J. W. G. Lund, C. Kipling and E. D. LeCren, Hydrobiologia, 1958, 11, 143-170.

22 R. E. Martinez, O. S. Pokrovsky, J. Schott and E. H. Oelkers, J. Colloid Interface Sci., 2008, 323, 317-325.

23 M. Manciu, F. S. Manciu and E. Ruckenstein, Advances in Colloid and Interface Science, 2016, DOI: 10.1016/ j.cis.2016.06.006.
24 A. J. H. Pieterse and A. Cloot, Water Sci. Technol., 1997, 36(4), 111-118.

25 H. Ratnaweera, N. Hiller and U. Bunse, Environ. Int., 1999, 25(2-3), 347-355.

26 T. Saito, T. Takatsuka, T. Kato, K. Ishihara and K. Okuda, Arch. Oral Biol., 2001, 42, 539-545.

27 A. Schlesinger, D. Eisenstadt, A. Bar-Gil, H. Carmely, S. Einbinder and J. Gressel, Biotechnol. Adv., 2012, 30(5), 1023-1030.

28 E. L. Sharp, J. Banks, J. A. Billica, K. R. Gertig, R. K. Henderson, S. A. Parsons, D. Wilson and B. Jefferson, Water Sci. Technol.: Water Supply, 2005, 5, 49-56.

29 Q. Shen, J. Zhu, L. Cheng, J. Zhang, Z. Zhang and X. Xu, Desalination, 2011, 271, 236-240.

30 B. T. Smith and R. H. Davis, Algal Res., 2012, 1, 32-39.

31 A. Swanepoel, H. H. Du Preez, I. Dusrath and M. Rajele, Water Institute of Southern Africa (WISA 2008), Sun City, South Africa, 2008.

32 P. J. L. B. Williams and L. M. L. Laurens, Energy Environ. Sci., 2010, 3, 554.

33 T. Yang, D. Kwak, S. Kim, J. Lee and H. Jung, Water Sci. Technology: Water Supply, 2005, 4(28-4.30), 309-316.

34 H. Zou, G. Pan, H. Chen and X. Z. Yuan, Environ. Pollut., 2006, 141(2), 201-205. 